\title{
Estrogen-induced growth inhibition of human seminoma cells expressing estrogen receptor $\beta$ and aromatase
}

\author{
C Roger, S Lambard'1, A Bouskine, B Mograbi, D Chevallier, M Nebout, G Pointis, \\ $S$ Carreau ${ }^{1}$ and $\mathbf{P}$ Fenichel
}

INSERM U 670, 28 avenue de Valombrose, Faculté de Médecine, 06102 Nice Cedex 2, France

${ }^{1}$ UPRES EA 2608-USC INRA, Université-IBFA, Caen 14032, France

(Requests for offprints should be addressed to P Fenichel; Email: Fenichel@ unice.fr)

\begin{abstract}
It is now well established that estrogens participate in the control of normal spermatogenesis and endogenous or environmental estrogens are involved in pathological germ cell proliferation including testicular germ cell tumors. Studying a human testicular seminoma cell line, JKT-1, we show here that $17 \beta$-estradiol $\left(10^{-12}\right.$ to $\left.10^{-6} \mathrm{M}\right)$ induced in vitro a significant dose-dependent decrease of cell growth. This antiproliferative effect was maximum after 4 days of exposure at a physiologically intratesticular concentration of $10^{-9} \mathrm{M}$, close to the $K_{\mathrm{d}}$ of $\mathrm{ER}$, and reversed by ICI 182780, an ER antagonist, suggesting an ER-mediated pathway. By RT-PCR and Western blot we were able to confirm that JKT-1, like tumoral seminoma cells and normal human testicular basal germ cells, expresses estrogen receptor $\beta(E R \beta)$, including $E R \beta 1$ and $E R \beta 2$, a dominant negative variant, but not $E R \alpha$. Using immunofluorescence and confocal microscopy, ER $\beta$ was observed as perinuclear intracytoplasmic spots in JKT-1 and tumoral seminoma cells without significant translocation of ER $\beta$ into the nucleus, under $17 \beta$-estradiol exposure. Double staining observed by confocal microscopy revealed that ER $\beta$ colocalized in JKT-1 cells with cytochrome C, a mitochondrial marker. We report for the first time the expression of a functional aromatase complex in seminoma cells as assessed by RT-PCR, Western blot and enzymatic assay. Seminoma cells are able to respond to estrogens through a possible autocrine or paracrine loop. These preliminary results support estrogen-dependency of human testicular seminoma, the most frequent tumor of young men, and suggest potential pharmacological use. Whether this estrogen control, however, involves an ER $\beta$-mediated stimulation of cell apoptosis and/or an ER $\beta$-mediated inhibition of cell proliferation, remains to be further determined.
\end{abstract}

Journal of Molecular Endocrinology (2005) 35, 191-199

\section{Introduction}

Estrogens are important regulators of cell proliferation in many reproductive and extra-reproductive tissues in both sexes. This control is cell-specific, depending on the expression of two related estrogen receptors (ERs), $\mathrm{ER} \alpha$ and ER $\beta$, which are transcriptional factors (see review in Nilsson et al. 2001). There is compelling evidence that $\mathrm{ER} \alpha$ mediates the proliferative effects of estrogens in several so-called estrogen-dependent cancers, such as breast, uterus and ovary. Of particular interest, ER $\beta$, when coexpressed with $\mathrm{ER} \alpha$, reduces tumor cell proliferation (Speirs 2002), and its loss is associated with advanced tumoral stage in several cancers such as breast (Lazennec et al. 2001), ovary (Rutherford et al. 2000), prostate (Weihua et al. 2001) and colon (Konstantinopoulos et al. 2003).

Recently it has been suggested that estrogens, the archetype female hormones, could play a role in the control of male germ cell proliferation (see review in Jones \& Simpson 2000). Indeed, estrogen is found at a higher level in mature testis than in circulating plasma in relation to its production through testosterone conversion by aromatase complex (Carreau et al. 2002). Of particular interest, knockout $(\mathrm{KO})$ mice deficient in aromatase display infertility with aging (Fisher et al. 1998), and men with aromatase mutation present abnormal spermograms (Simpson 1998). In human testis, gonocytes (fetal germ cells which differentiate into spermatogonia after birth) (Gaskell et al. 2003) and most adult germ cells (Mäkinen et al. 2001) express ER $\beta$. Estrogens have been shown in vitro to control gonocyte proliferation in the rat $(\mathrm{Li}$ et al. 1997) and recent analysis of neonatal testes from ER $\beta \mathrm{KO}$ mice has confirmed the link between endogenous estrogens, ER $\beta$ and gonocyte survival (Delbes et al. 2004). However, the precise role of estrogens and their receptors (Dupont et al. 2000) and the underlying mechanism(s) in the control of normal and malignant germ cell proliferation remain to be determined.

This issue is of particular concern since environmental estrogens have been blamed for the increasing incidence 
Table 1 Sequences of the human ER and aromatase primers

\begin{tabular}{ll} 
& \multicolumn{1}{l}{ Primer } \\
\cline { 2 - 2 } Name & \\
hER $\alpha$ F & 5'-AGA-CAT-GAG-AGC-TGC-CAA-CC-3' \\
hER $\alpha$ R & 5'-GCC-AGG-CAC-ATT-CTA-GAA-GG-3' \\
hER $\beta$ F & 5'-TCA-CAT-CTG-TAT-GCG-GAA-CC-3' \\
hER $\beta$ R & 5'-CGT-ACC-ACT-TCC-GAA-GTC-GG-3' \\
hER $\beta 2$ F & 5'-CGA-TGC-TTT-GGT-TTG-GTG-AT-3' \\
hER $\beta 2$ R & 5'-CTT-TAG-GCC-ACC-GAG-TTG-ATT-3' \\
Aromatase F & 5'-AAA-GGA-AAT-CCA-TGT-TAT-TGG-TGG-3' \\
Aromatase R & 5'-GTA-TCT-TCT-GTA-TGC-TCT-CAA-CAC-ACT-GTG-3' \\
&
\end{tabular}

$F$, forward; R, reverse.

of infertility and testicular cancer, the most frequent cancer of the young man (Skakkebaek et al. 1998). Indeed, deleterious effects of adult male reproductive function have been observed after fetal or prenatal exposure to diethylstilbestrol, a potent synthetic estrogen (Walker 1989, Giusti et al 1995). However, little is known of the possible estrogen-dependency of seminoma, the most frequent malignant testicular germ cell proliferation, partly due to the lack of available in vitro models. We therefore took advantage of a pure human testicular seminoma cell line, JKT-1 (Kinugawa et al. 1998, Roger et al. 2004), to assess the in vitro effects of estrogens on seminoma cell proliferation, to characterize ER subtypes and to test for a functional aromatase complex.

\section{Materials and methods}

\section{Tissue preparation and cell culture}

Normal and seminoma testicular tissues obtained according to the French ethical guidelines were immediately snap-frozen or fixed and embedded in paraffin wax. The three testicular tumors were classified as pure seminoma by histological analysis and by positive staining for placental alkaline phosphatase (PlAP), a specific seminoma marker (Giwercman et al. 1991). The JKT-1 cells, described as a pure human seminoma cell line (Kinugawa et al. 1998), also expressing PIAP (Roger et al. 2004), were maintained in DMEM supplemented with $10 \%$ fetal bovine serum (FBS) (Gibco BRL). For estrogen stimulation, JKT-1 cells were plated in the above complete medium, estrogen-starved for $24 \mathrm{~h}$ in fresh phenol red-free DMEM supplemented with $10 \%$ charcoal-stripped serum (3 g charcoal-coated dextran/50 ml FBS), before adding every culture day $17 \beta$-estradiol (Sigma), ICI 182780 (Falsodex; Astra-Zeneca, Birmingham, UK) or ethanol as vehicle control. Human granulosa-lutein cells were obtained from the in vitro fertilization center of CHRU of Caen. MCF-7 cells (LGG-Promochem,
Molsheim, France), a human breast cancer cell line, were cultured in DMEM 10\% serum.

\section{Cell proliferation study}

JKT-1 cells were treated with steroids diluted in ethanol and counted for 1-6 days and compared with controls (cells cultured in steroid-free medium with ethanol). Results were expressed as percentages of variation as compared with the control. A nonparametric Mann-Whitney test was used for statistical analysis.

\section{RT-PCR analysis}

Total RNAs were prepared from normal human testis, seminoma tumors, JKT-1, MCF-7 and granulosa cells. RT-PCR analysis was performed as described previously (Roger et al. 2004). ER primers (Eurogentec, Seraing, Belgium) were designed from published sequences (Otsuki et al. 2000, Mäkinen et al. 2001, Lambard et al. 2004) (see Table 1). Cycling parameters were as follows: denaturation at $94{ }^{\circ} \mathrm{C}$ for $1 \mathrm{~min}$; annealing for $\mathrm{ER} \beta$, ER $\alpha$ and aromatase respectively at 58,59 and $60{ }^{\circ} \mathrm{C}$, for $1 \mathrm{~min}$, and extension at $72{ }^{\circ} \mathrm{C}$ for $1 \mathrm{~min} ; 35$ cycles were performed then followed by a final extension step of $10 \mathrm{~min}$.

\section{Western blot analysis}

Sections of normal testis and seminoma tumors as well as cultured JKT-1, MCF-7 and granulosa cells were directly lysed in $600 \mu \mathrm{l} \mathrm{Brij/NP40} \mathrm{lysis} \mathrm{buffer}$ (50 mM Tris-HCl, pH 7.5, 1\% NP40, 1\% Brij 96, $1 \mathrm{mM} \quad \mathrm{Na}_{3} \mathrm{VO}_{4}, 10 \mathrm{mM}$ sodium fluoride, $10 \mathrm{mM}$ $\beta$-glycerophopshate, $2 \mathrm{mM}$ EDTA, $1 \mathrm{mM}$ aprotinin, $25 \mathrm{mM}$ leupeptin, $1 \mathrm{mM}$ pepstatin, $2 \mathrm{mM}$ phenylmethylsulfonyl fluoride). Lysates were sonicated $10 \mathrm{~s}$ on ice twice, then centrifuged for $20 \mathrm{~min}$ at $22000 \boldsymbol{g}$. Lysates were analyzed by Western blotting as described previously (Defamie et al. 2001) with a rabbit anti-ER $\alpha$ 
antibody (sc-543; Santa Cruz Biotechnology, Inc., Santa Cruz, CA, USA), a goat polyclonal anti-ER $\beta$ antibody raised against a peptide mapping near the carboxyterminus of ER $\beta$ which recognizes both ER $\beta 1$ and ER $\beta 2$ and which does not cross-react with ER $\alpha$ (sc-6822; Santa Gruz), a rabbit polyclonal anti-ER $\beta$ antibody raised against the amino-terminus of ER $\beta$ (Upstate Biotechnology, Lake Placid, NY, USA) or a mouse monoclonal anti-aromatase antibody (1:500, kindly provided by Dr Saunders, Serotec, UK) which recognizes mammalian aromatase (Turner et al. 2002), in $0 \cdot 1 \%$ Tween 20, $10 \mathrm{mM}$ Tris, $15 \mathrm{mM} \mathrm{NaCl}, \mathrm{pH} 7 \cdot 4$, containing $1 \%$ non-fat dried milk.

\section{Immunocytochemical procedures}

JKT-1 and MCF-7 cells were prepared for immunofluorescence analysis as described previously (Defamie et al. 2001, Roger et al. 2004). Slides of frozen testicular tissue and tumors were fixed in methanol at $-20{ }^{\circ} \mathrm{C}$ for $7 \mathrm{~min}$, washed twice in PBS and then saturated in $\mathrm{PBS} /$ saponine $0.5 \% / \mathrm{SVF}$ or fetal calf serum $5 \%$ for 30 min. ER $\alpha$ and ER $\beta$ were detected using a rabbit anti-ER $\alpha$ (Santa Cruz; $200 \mathrm{mg} / \mathrm{ml}$ ) and a goat anti-ER $\beta$ (Santa Cruz; $200 \mathrm{mg} / \mathrm{ml}$ ). After three washes in $\mathrm{PBS} /$ saponine $0 \cdot 5 \%$, the antibodies were detected using an FITC-labeled anti-rabbit (Dako, 1/50) and an FITC-labeled anti-goat (Dako, 1/50 in PBS with 5\% goat serum). Nuclei were stained by propidium iodide $(30 \mu \mathrm{g} / \mathrm{ml})$. Colocalization of ER $\beta$ was performed by using a mouse anti-cytochrome $\mathrm{C}$ antibody (Becton Dickinson) revealed by an anti-mouse-Texas Red sheep antibody (Amersham). Sections were examined with a confocal laser scanning microscope (Leica TCS SP).

\section{Aromatase activity}

Microsomal fractions from JKT-1 and granulosa cells (used as a positive control) were prepared as previously described (Levallet et al. 1998). The aromatase activity was assessed by measurement of ${ }^{3} \mathrm{H}_{2} \mathrm{O}$ released from $\left[1 \beta-{ }^{3} \mathrm{H}\right]$ androst-4-ene-3,17-dione (New England Nuclear, Les Ulis, France) as described before (Lephart \& Simpson 1991). Blank values were obtained from identical incubations in the absence of microsomes. The activity was expressed in pmol ${ }^{3} \mathrm{H}_{2} \mathrm{O}$ produced per milligram of protein per hour.

\section{Results}

\section{Effects of estrogens on seminoma cell proliferation}

We examined first the effects of $17 \beta$-estradiol and ICI 182780, an ER antagonist, on seminoma cell proliferation. As shown on Fig. 1A, treatment of JKT-1 cells with estradiol $\left(10^{-12}\right.$ to $\left.10^{-6} \mathrm{M}\right)$ for $24 \mathrm{~h}$ induced a
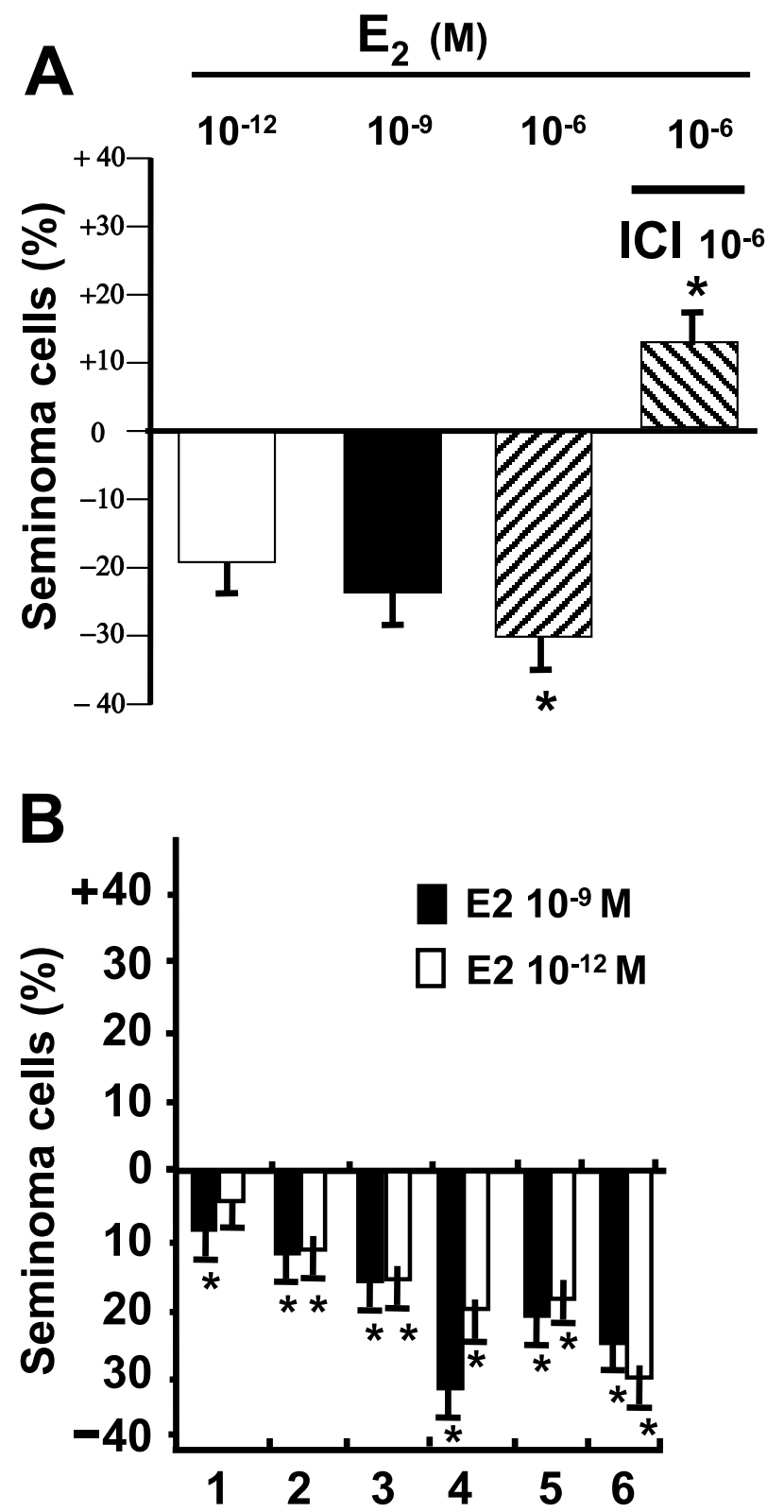

Figure 1 Effect of $17 \beta$-estradiol on JKT-1 cell proliferation. (A) Dose-response study. JKT-1 cells were incubated for $48 \mathrm{~h}$ with steroid-free medium or medium containing $10^{-12}$ to $10^{-6} \mathrm{M}$ $17-\beta$-estradiol. Competition between ICl 182780 and $17 \beta$-estradiol at the final concentration of $10^{-6} \mathrm{M}$ is also represented. The results are given as means \pm S.E.M. of three independent experiments, and show the percentage of cell numbers compared with control (steroid-free medium with ethanol). ${ }^{*} P<0.05$. (B) Kinetic study. Cell proliferation was evaluated during 6 days of culture with or without $17 \beta$-estradiol at low concentrations of $10^{-12}$ and $10^{-9} \mathrm{M}$. The results are given as means \pm S.E.M. of three separate experiments, with two replicates per experiment considering the percentage of variation of cell number compared with control (steroid-free medium with ethanol). ${ }^{*} P<0.05$. 
$E R \alpha$
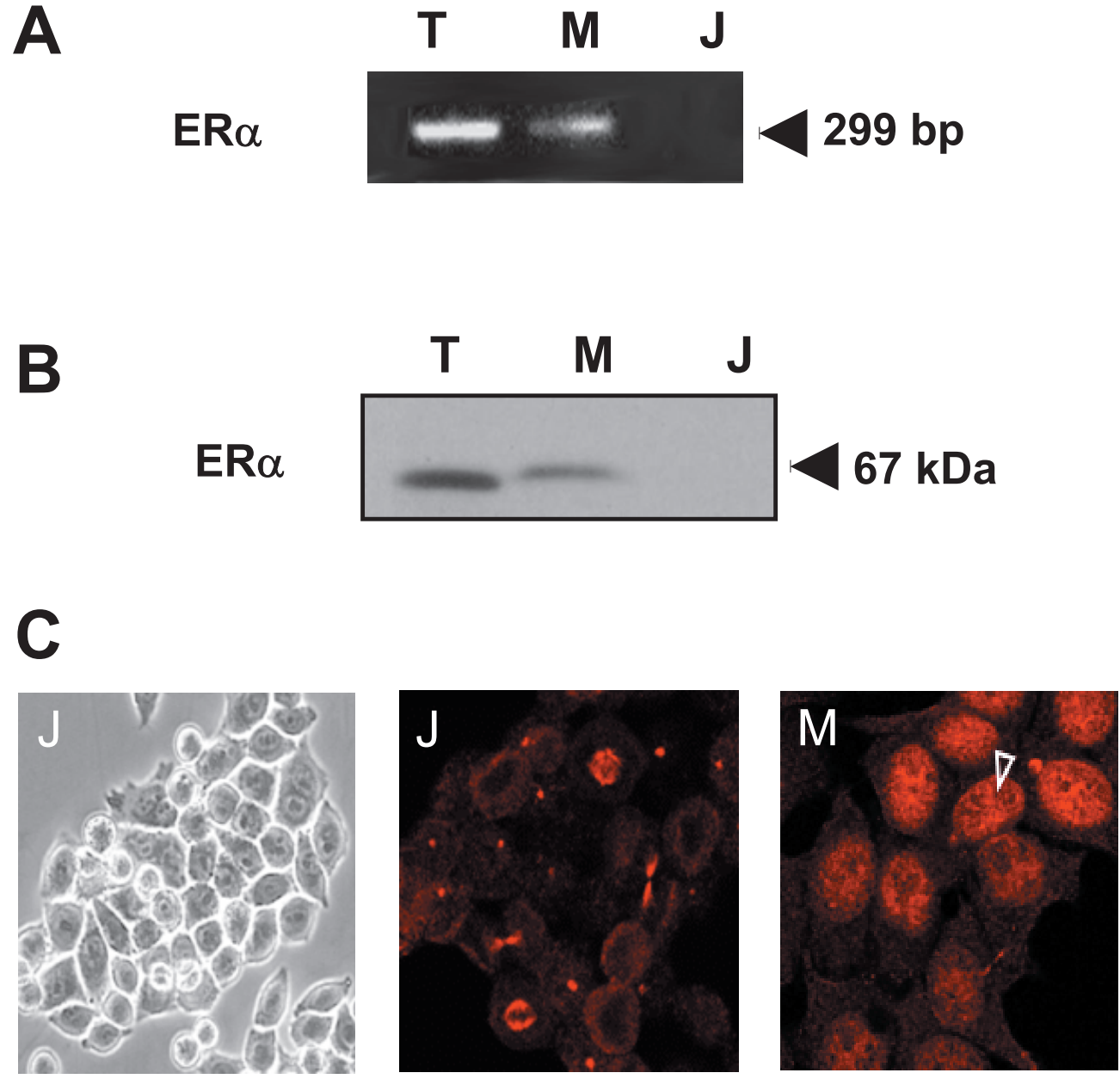

Figure 2 ER $\alpha$ expression. RT-PCR analysis (A), Western blot analysis (B) and immunofluorescence analysis by confocal microscopy (C) in JKT-1 ('J') cells, MCF-7 ('M') cells, and normal testicular tissue ('T'). JKT-1 cells, shown in phase contrast (left) are negative for ER $\alpha$. MCF-7 cells presenting an intense nuclear staining are shown as a positive control.

dose-dependent inhibition of cell growth, reaching a $30 \%$ decrease at $10^{-6} \mathrm{M}$ estradiol as compared with control cells cultured without estradiol. Co-treatment with ICI $182780\left(10^{-6} \mathrm{M}\right)$, was able to reverse significantly $(P<0 \cdot 05)$ the inhibition induced by $10^{-6} \mathrm{M}$ estradiol alone (Fig. 1B). JKT-1 cells were then cultured for 6 days without reaching sub-confluency with and without low concentrations of estradiol $\left(10^{-9}\right.$ and $\left.10^{-12} \mathrm{M}\right)$. Relative inhibition of cell proliferation increased from the first day to the sixth day, reaching $30 \%$ on the fourth day at the physiological concentration of $10^{-9} \mathrm{M}$.

\section{ER expression in seminoma cells}

Considering ER $\alpha$, neither the transcript nor the protein could be identified in the pure seminoma cell line, JKT-1 (Fig. 2A and B) compared with MCF-7, a human breast cancer cell line used as positive control and normal testicular tissue, which also expressed a transcript at the expected size. Consistently, indirect immunofluorescence analysis confirmed the lack of expression of ER $\alpha$ in JKT-1 cells (Fig. 2C) compared with a strong nuclear staining in MCF-7 cells. Considering ER $\beta$, RT-PGR analysis identified the ER $\beta 1$ transcript at the expected size of 346 bp in JKT-1 cells (Fig. 3A). In addition to ER $\beta 1$, RT-PGR detected also the transcript of ER $\beta 2$ (also referred as ER $\beta C x$ ), a dominant negative splice variant (Saunders et al. 2002) (Fig. 3A). Both transcripts were also identified in three seminoma tumoral fragments and in normal testicular tissue (Fig. 3A). Using an anti-ER $\beta$ antibody raised against the carboxy-terminal part of $\operatorname{ER} \beta$ and which recognizes both ER $\beta 1$ and ER $\beta 2$ isoforms, an intense band was detected by Western blotting at $59 \mathrm{kDa}$ (Fig. 3B) corresponding to the molecular mass of ER $\beta 1$ 

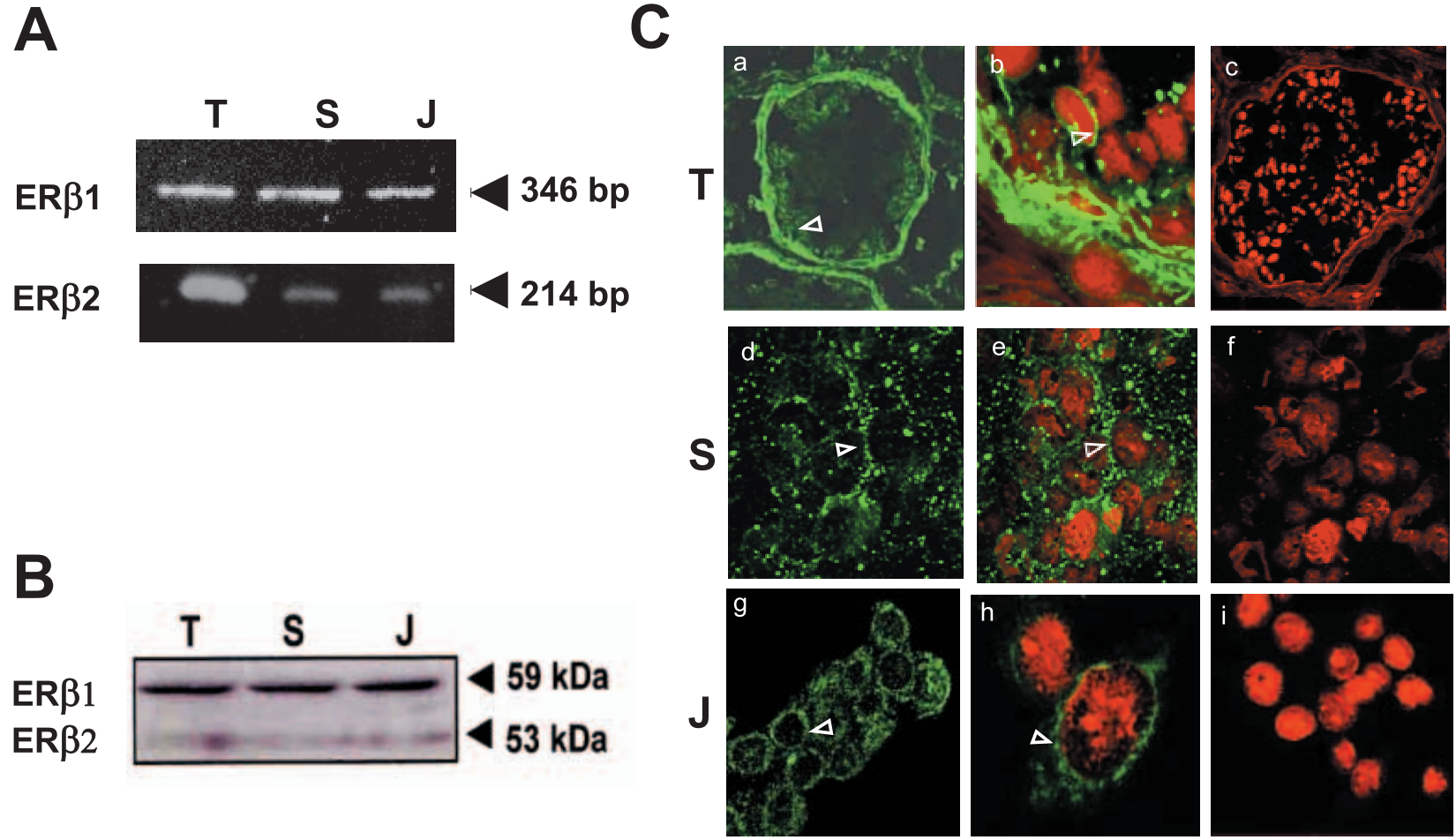

Figure 3 ER $\beta$ expression. RT-PCR analysis with primers for ER $\beta 1$ and ER $\beta 2$ (A); Western blot analysis using the Santa Cruz anti-ER $\beta$ antibody which recognizes both ER $\beta 1$ and ER $\beta 2(B)$; immunofluorescence analysis by confocal microscopy (C) of normal testicular tissue ('T') (a-c), tumoral seminoma cells ('S') (d-f) and JKT-1 ('J') ( $g-i)$ with nuclei counterstained with propidium iodide $(b, c, e, f, h, i)$. First antibody has been omitted as an immunofluorescent negative control in $c$, $f$ and $i$. Note that on testicular sections the peritubular myoepithelial cells and the intratubular basal germ cells are positive for ER $\beta$ (white arrow). Tumoral seminoma cells $(d, e)$, as JKT-1 cells $(g, h)$, show intense perinuclear intracytoplasmic staining with very little intranuclear staining. The same staining was found in three different seminoma tumors examined (data not shown).

long form. This band was associated with a weaker $53 \mathrm{kDa}$ band, which may represent ER $\beta 2$ or another ER $\beta$ isoform (Fig. 3B). The same pattern was obtained with a second polyclonal antibody (Upstate Biotechnology) recognizing the amino-terminal part of $\operatorname{ER} \beta$ (data not shown). Two bands were detected with a similar pattern in tumoral seminoma cells and normal testicular tissue (Fig. 3B). Indirect immunofluorescence analysis with nuclear propidium iodide counterstaining observed by confocal microscopy revealed that $\operatorname{ER} \beta$ was expressed in normal testicular tissue, in myoepithelial cells surrounding the seminiferous tubules and in intratubular basal round germ cells which showed a punctuate cytoplasmic localization (Fig. 3Cb), as observed in tumoral seminoma cells (Fig. 3Cd and e). In JKT-1 cells, ER $\beta$ was identified as intense perinuclear intracytoplasmic spots associated with a weak nuclear staining (Fig. $3 \mathrm{Cg}$ and h). Further, no ER $\beta$ signal was seen in the cells in which the primary antibody was omitted (Fig. 3Cic, f and i). Moreover, no evident nuclear translocation could be observed under a $24 \mathrm{~h}$ estrogen exposure (Fig. 4A) and differed from what has been reported usually for steroid receptors (Picard et al.
1990). Double-staining experiments, using immunofluorescence and confocal microscopy, allowed partial colocalization of ER $\beta$, identified by an FITG-antibody, with cytochrome $\mathrm{C}$, a mitochondrial marker, revealed by a Texas Red antibody (Fig. 4B).

\section{Aromatase expression}

P450 aromatase mRNAs were detected by RT-PGR at the expected size of $424 \mathrm{bp}$, in JKT-1 cells, as in granulosa cells used as a positive control (Fig. 5A). Such an expression was also identified in normal human testicular tissue and in three seminoma tumors, although with a weaker intensity (Fig. 5B). Western blot analysis of microsomes from JKT-1 cells revealed the expression of the aromatase protein as a 55/49 kDa doublet including one band at the expected mass of $55 \mathrm{kDa}$, as obtained with granulosa cells used as the positive control (Fig. 5B). The second band of $49 \mathrm{kDa}$ may correspond to a less-glycosylated isoform already described in germ cells (Lambard et al. 2004). The tritiated-water release assay demonstrated that this aromatase complex was functional and allowed the measurement of a basal activity of 


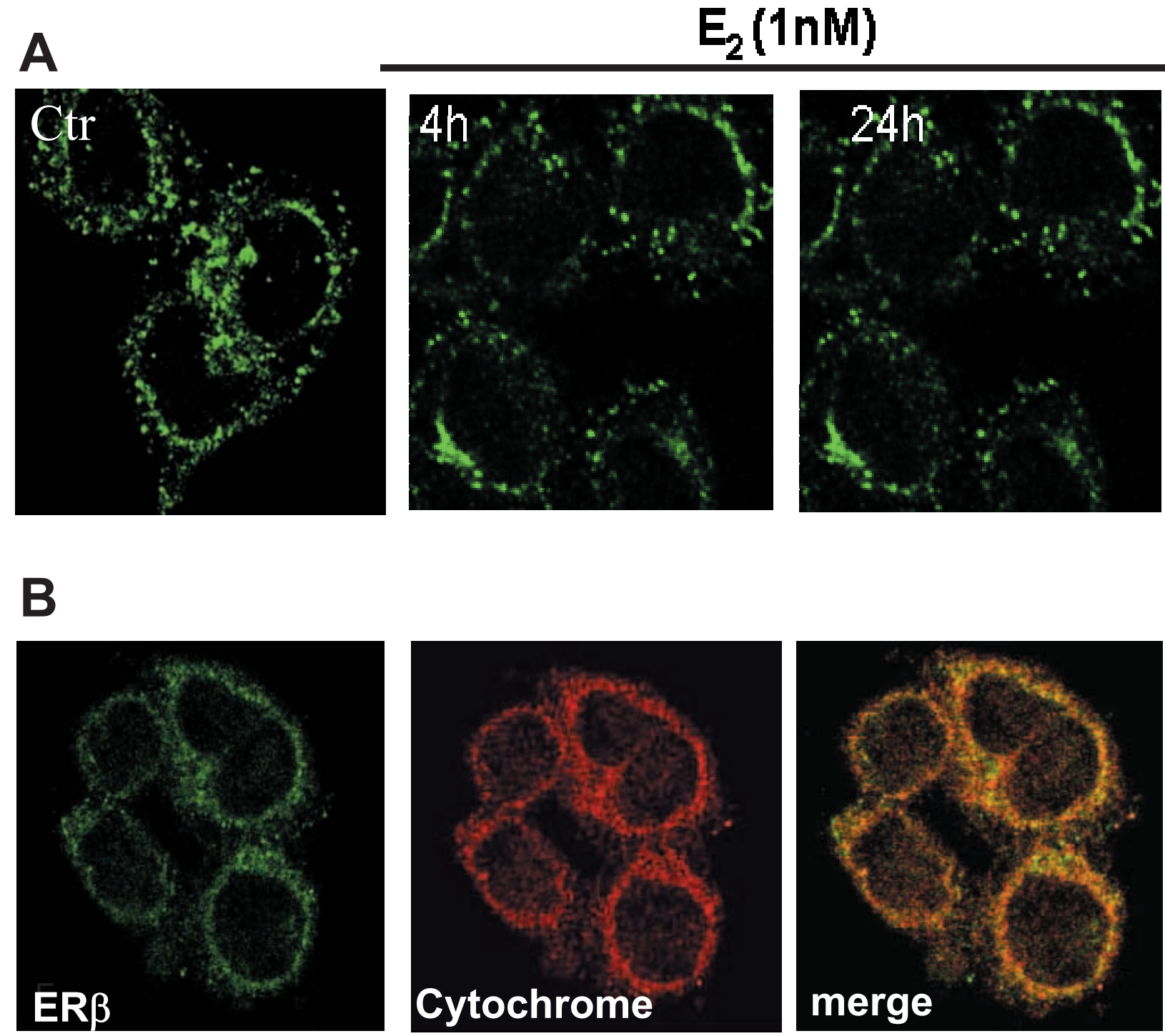

\section{$E_{2}(1 n M)$}

Figure 4 ER $\beta$ expression in JKT-1 cells analyzed by immunofluorescence and confocal microscopy. (A) Estrogen exposure $\left(10^{-6} \mathrm{M}\right)$ for 4 and $24 \mathrm{~h}$. Lack of significant nuclear translocation of ER $\beta$. (B) ER $\beta$ revealed by FITC and cytochrome $C$ revealed by Texas Red; colocalization in yellow (merged).

$96 \cdot 0 \pm 26 \cdot 4 \mathrm{fmol} / \mathrm{h}$ per $\mathrm{mg}$ protein (mean \pm S.D. of three activities measured in duplicate). This activity was compared with the much higher one $(4.71 \mathrm{pmol} / \mathrm{h}$ per mg protein) observed with granulosa cells.

\section{Discussion}

Our study provides several lines of evidence suggesting that testicular seminoma might be an estrogen-dependent cancer. First, we reported a previously unrecognized inhibitory effect of estrogen on seminoma cell proliferation. Indeed, addition of exogenous $17 \beta$-estradiol inhib- ited JKT-1 cell growth at the physiological concentration of $10^{-9} \mathrm{M}$, supporting the in vivo relevance of this result. Seminomas, like most testicular tumors, are believed to arise from malignant fetal gonocytes (Giwercman et al. 1991). Seminoma cells share with gonocytes several specific markers such as PIAP that we identified in JKT-1 cells (Roger et al. 2004). Li et al. (1997) have reported that estradiol was able to stimulate rat gonocyte proliferation in vitro, but this mitogenic effect was comparable with that triggered by platelet-derived growth factor and supposed to be mediated through a rapid, membranous, receptor kinase-dependent pathway. Such a rapid and membranous estrogen induction often associated with 
A

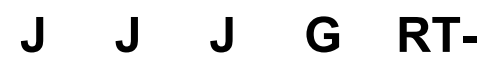

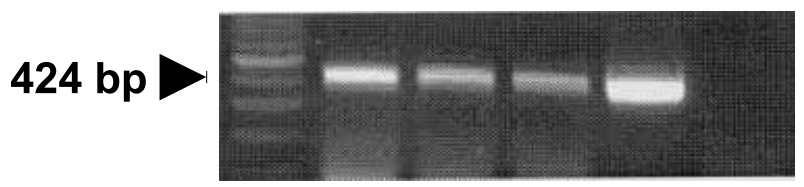
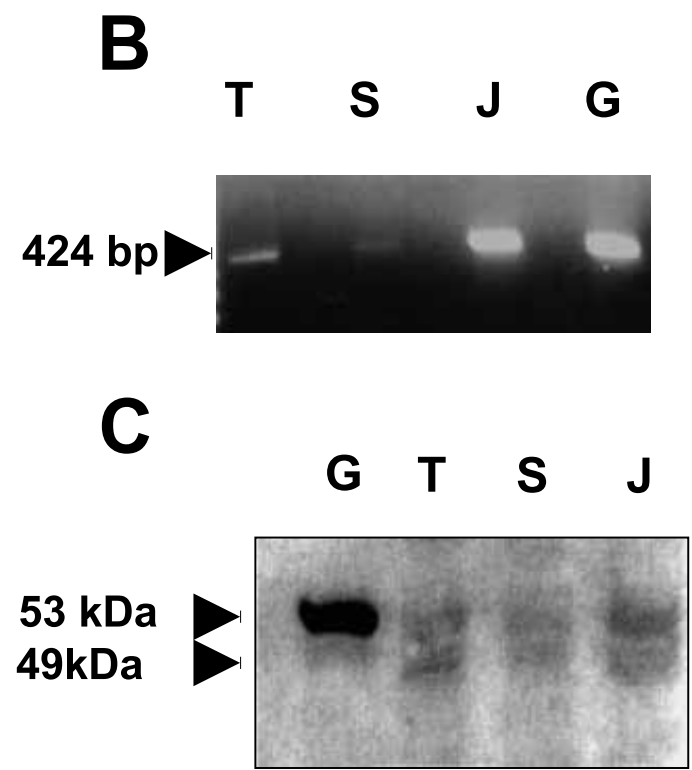

Figure 5 P450 aromatase expression. Analysis of P450 aromatase mRNAs and protein expression by RT-PCR (A) and Western blot (B) in JKT-1 cells ('J'), human granulosa cells ('G'), human normal testis ('T'), and one out of three seminomas tested ('S'). RT-, negative control.

activation of MAP kinases, has now been described in many models (Kelly \& Levin 2001). However, it did not seem to be involved in our model, since $17 \beta$-estradiol linked to BSA did not reproduce any growth inhibition (data not shown). More recently, analysis of neonatal testes of ER $\beta \mathrm{KO}$ transgenic mice and organotypic testis culture under estrogen exposure, have allowed Delbes et al. (2004) to propose that estrogens may physiologically control perinatal gonocyte proliferation through both an ER $\beta$-mediated induction of apoptosis and an ER $\beta$-mediated inhibition of proliferation (Delbes et al. 2004). Moreover, in several estrogen-dependent cancers such as breast (Lazennec et al. 2001), prostate (Weihua et al. 2001), ovarian (Rutherford et al. 2000) and colon cancers (Fiorelli et al. 1999; Konstantinopoulos et al. 2003), estrogen has been shown to decrease, via ER $\beta$, tumor cell proliferation. This suppressive effect of ER $\beta$ may occur via a negative control of cell cycle gene transcription, as shown for cyclin D1 whose promoting sequence contains AP-1 sites (Liu et al. 2002). It has also been suggested in several cell models that estrogens could stimulate apoptosis (Jenkins et al. 2001, Song \& Santen 2003, Moore et al. 2005), possibly through an ER $\beta$-mediated process (Qiu et al. 2002).

Expression of ER $\beta$ in testicular tumors, including seminoma, has been identified (Pais et al. 2003) and found by real-time PCR to be down-regulated when compared with normal testicular tissue (Hirvonen-Santti et al. 2003). By studying JKT-1 cells and three tumors, we confirmed that seminoma cells express ER $\beta$ but not $\mathrm{ER} \alpha$. In addition to $\mathrm{ER} \beta_{1}$, we detected by RT-PCR, for the first time, the expression of $\mathrm{ER} \beta_{2}$ (also referred to as $\mathrm{ER} \beta \mathrm{Cx}$ ), a splice variant of $\mathrm{ER} \beta_{1}$ (Saunders et al. 2002), as reported in normal germ cells (Mäkinen et al. 2001). $\operatorname{ER} \beta_{1}$ was readily detected by Western blotting at the expected mass of $59 \mathrm{kDa}$, using two different antibodies raised against the carboxy- or amino-terminal part of the protein. The associated $53 \mathrm{kDa}$ band observed is likely to represent $\mathrm{ER} \beta_{2}$ or alternatively another isoform corresponding to one of the splice variants described for ER $\beta$ (Lehman \& Wilson 1998), especially in testicular cells (Aschim et al. 2004). An ER $\beta$-mediated inhibitory control of JKT-1 cells under estrogen exposure is supported by the following observations: (i) ER $\beta$ but not ER $\alpha$ was expressed in JKT-1 cells; (ii) the antiproliferative effect induced by estradiol occurred at a concentration close to the $K_{\mathrm{d}}$ of ER $\left(1-4 \times 10^{-10} \mathrm{M}\right)$; (iii) this inhibition was reversed by the classic ER antagonist ICI 182780; and (iv) ER $\beta$ has now been shown to act as a suppressive agent in several estrogen-dependent cancers (Speirs 2002). Very recently $\mathrm{ER} \beta$ has been localized in the mitochondria in rat primary neurons, human cardiomyocytes and human lens cells (Cammarata et al. 2004, Yang et al. 2004); it is suggested to participate to the regulation of several estrogen-dependent mitochondrial functions (Yang et al. 2004), such as apoptosis (Moore et al. 2005). The cytoplasmic perinuclear localization for $\operatorname{ER} \beta$ that we found in JKT-1 cells without any nuclear translocation under estrogen exposure, its colocalization with cytochrome $\mathrm{C}$, and the estradiol-induced cell growth inhibition observed, may suggest such a mechanism.

The molecular mechanism(s) responsible for this estrogen-dependent seminoma cell growth inhibition is now under investigation in our laboratory. Using neutralization of ER $\beta$ expression by siRNA, cell cycle gene expression and apoptosis analysis we should be able to demonstrate whether an ER $\beta$-mediated inhibition of cell proliferation and/or an ER $\beta$-mediated stimulation of apoptosis are involved in this process.

So far, aromatase has been reported in mature testis in both somatic and germ cells (Levallet et al. 1998; Lambard et al. 2004), and was suggested to be responsible for gynecomastia in one patient bearing a seminoma (Duparc et al. 2003). We report here for the 
first time the characterization of a functional aromatase complex (transcript, protein and enzymatic activity) in a pure human seminoma cell line, underlining the ability of intratesticular seminoma cells to convert testosterone into estradiol and to respond to it through an autocrine and/or a paracrine loop.

Altogether, these results suggest estrogen-dependency for testicular seminoma and support a possible participation of endogenous or environmental estrogens in testicular carcinogenesis. Whether the expression level of ER $\beta$ in seminoma could represent a prognostic marker related to the degree of malignancy as described for other estrogen-dependent cancers (Speirs 2002), and whether its apparent suppressive role could be used for a therapeutic goal, require further investigation.

\section{Acknowledgements}

We thank Dr H Tanaka for kindly providing JKT-1 cells, Dr C Pradier for statistical analysis, Prof. J F Michiels for providing seminoma tissues and Dr Tresca Patricia from Astra-Zeneca Laboratories for providing Faslodex. This work was supported in part by a grant from Fond d'Aide à la Recherche Organon (FARO), and by la Ligue Contre le Cancer des Alpes Maritimes. C R was supported by a grant from the Association pour la Recherche contre le Cancer (ARG). The authors declare that there is no conflict of interest that would prejudice the impartiality of this scientific work.

\section{References}

Aschim EL, Saether T, Grotmol T \& Haugen TB 2004 Differential distribution of splice variants of estrogen receptor beta in human testicular cells suggests specific functions in spermatogenesis. Fournal of Steroid Biochemistry and Molecular Biology 92 97-106.

Cammarata PR, Chu S, Moor A, Wang Z, Yang SH \& Simpkins JW 2004 Subcellular distribution of native estrogen receptor $\alpha$ and $\beta$ subtypes in cultured human lens epithelial cells. Experimental Eve Research 78 861-871.

Carreau S, Bourguiba S, Lambard S, Galeraud-Denis I, Genissel C \& Levallet J 2002 Reproductive system: aromatase and estrogens. Molecular and Cellular Endocrinology 193 137-144.

Defamie N, Mograbi B, Roger C, Cronier L, Malassine A, Brucker-Davis F, Fenichel P, Segretain D \& Pointis G 2001 Disruption of gap junctional intercellular communication by lindane is associated with aberrant localization of connexin 43 and zonula occludens-1 in 42 GPA9 Sertoli cells. Carcinogenesis 22 $1537-1542$.

Delbes G, Levacher G, Pairault C, Racine C, Duquesne C, Krust A \& Habert R 2004 ER(beta)-mediated inhibition of male germ cell line development in mice by endogenous estrogens during perinatal life. Endocrinology 145 3395-3403.

Duparc C, Boissiere-Veverka G, Lefebvre H, Laquerriere A, Vuillermet P, Landreat A, Ivell R, DeRoux N \& Kuhn JM 2003 An estrogen-producing seminoma responsible for gynaecomastia. Hormone and Metabolic Research 35 324-329.

Dupont S, Krust A, Gansmuller A, Dierich A, Chambon P \& Mark M 2000 Effect of single and compound knockouts of estrogen receptors alpha (ERalpha) and beta (ERbeta) on mouse reproductive phenotypes. Development 127 4277-4291.

Fiorelli G, Picariello L, Martineti V, Tonelli F \& Brandi ML 1999 Functional estrogen receptor beta in colon cancer cells. Biochemical and Biophysical Research Communications 261 521-527.

Fisher CR, Graves KH, Parlow AF \& Simpson ER 1998 Characterization of mice deficient in aromatase (ArKO) because of targeted disruption of the cyp19 gene. Proc Natl Acad Sci 95 6965-6970.

Gaskell TL, Robinson LL, Groome NP, Anderson RA \& Saunders PT 2003 Differential expression of two estrogen receptor beta isoforms in the human fetal testis during the second trimester of pregnancy. Fournal of Clinical Endocrinology and Metabolism $\mathbf{8 8}$ $424-432$.

Giusti RM, Iwamoto K \& Hatch EE 1995 Diethylstilbestrol revisited: a review of the long-term health effects. Annals of Internal Medicine 122 778-788.

Giwercman A, Cantell L \& Marks A 1991 Placenta-like alkaline phosphatase as a marker of carcinoma in situ of the testis. Comparison with monoclonal antibodies M2A and 43-9F. APMIS: Acta Pathologica, Microbiologica, et Immunologica Scandinavica 7 $586-594$.

Hirvonen-Santti SJ, Rannikko A, Santti H, Savolainen S, Nyberg M, Jänne OA \& Palvimo JJ 2003 Down-regulation of estrogen receptor $\beta$ and transcriptional coregulator SNURF/RNF4 in testicular germ cell cancer. European Urology 44 742-747.

Jenkins K, Suwannaroj S, Elbourne KB, Ndebele K \& McMurray RW 2001 17- $\beta$-estradiol alters Jurkat lymphocyte cell cycling and induces apoptosis through suppression of Bcl-2 and cyclin A. International Immunopharmacology 1 1897-1911.

Jones ME \& Simpson ER 2000 Estrogens in male reproduction. Baillieres Best Practice and Research. Clinical Endocrinology and Metabolism 14 505-516.

Kelly MT \& Levin ER 2001 Rapid actions of plasma membrane estrogen receptors. Trends in Endocrinology and Metabolism 12 152-156.

Kinugawa K, Hyodo F, Matsuki T, Jo Y, Furukawa Y, Ueki A \& Tanaka H 1998 Establishment and characterization of a new human testicular seminoma cell line, JKT-1. International fournal of Urology 5 282-287.

Konstantinopoulos PA, Kominea A, Vandoros G, Sykiotis GP, Andricopoulos P, Varakis I, Sotiropoulou-Bonikou G \& Papavassiliou AG 2003 Estrogen receptor beta (ERbeta) is abundantly expressed in normal colonic mucosa, but declines in colon adenocarcinoma paralleling the tumour's dedifferentiation. European Fournal of Cancer 39 1251-1258.

Lambard S, Galeraud-Denis I, Saunders PTK \& Carreau S 2004 Human immature germ cells and ejaculated spermatozoa contain aromatase and estrogen receptors. Fournal of Molecular Endocrinology 32 279-289.

Lazennec G, Bresson D, Lucas A, Chauveau C \& Vignon F 2001 ER beta inhibits proliferation and invasion of breast cancer cells. Endocrinology 142 4120-4130.

Lehmann JM \& Willson TM 1998 Cloning and characterization of human estrogen receptor $\beta$ isoforms. Biochemical and Biophysical Research Communications 247 75-78.

Lephart ED \& Simpson ER. Assay of aromatase activity 1991 Methods in Enzymology 206 477-483.

Levallet J, Bilinska B, Mittre H, Genissel C, Fresnel L \& Carreau S 1998 Expression and immunolocalization of functional cytochrome P450 aromatase in mature rat testicular cells. Biology of Reproduction $\mathbf{5 8}$ 919-926.

Li H, Papadopoulos V, Vidic B, Dym M \& Culty M 1997 Regulation of rat testis gonocyte proliferation by platelet-derived growth factor and estradiol: identification of signaling mechanisms involved. Endocrinology 138 1289-1298.

Mäkinen S, Makela S, Weihua Z, Warner M, Rosenlund B, Salmi S, Hovatta O \& Gustafsson JK 2001 Localization of estrogen 
receptors alpha and beta in human testis. Molecular Human Reproduction 7 497-503.

Moore JT, McKee DD, Slentz-Kesler K, Moore LB, Jones SA, Horne EL, Su JL, Kliever SA, Mishra DP \& Shaha C 2005 Estrogen induced spermatogenic cell apoptosis occur via the mitochondrial pathway: role of superoxide and nitric oxide. Journal of Biological Chemistry (In Press).

Nilsson S, Makela S, Treuter E, Tujague M, Thomsen J, Andersson G, Enmark E, Pettersson K, Warner M \& Gustafsson JA 2001 Mechanisms of estrogen action. Physiological Reviews 81 1535-1565.

Otsuki T, Yamada O, Kurebayashi J, Moriya T, Sakaguchi H, Kunisue H, Yata K, Uno M, Yawata Y \& Ueki A 2000 Estrogen receptors in human myeloma cells. Cancer Research 60 1434-1441.

Pais V, Leav I, Lau KM, Jiang Z \& Ho SM 2003 Estrogen receptor- $\beta$ expression in human testicular germ cell tumors. Clinical Cancer Research 9 4475-4482.

Picard D, Kumar V, Chambon P \& Yanamoto KR 1990 Signal transduction by steroid hormones: nuclear localization is differentially regulated in estrogen and glucocorticoid receptor. Cell Regulation 1 291-299.

Qiu Y, Waters A, Lewis E, Langman MJS \& Eggo MC 2002 Oestrogen-induced apoptosis in colonocytes expressing oestrogen receptor $\beta$. Fournal of Endocrinology 174 369-377.

Roger C, Mograbi B, Chevallier D, Michiels JF, Tanaka H, Segretain D, Pointis G \& Fénichel P 2004 Disrupted traffic of connexin 43 in human testicular seminoma cells: overexpression of $\mathrm{Cx} 43$ induces membrane location and cell proliferation decrease. Fournal of Pathology 202 241-246.

Rutherford T, Brown WD, Sapi E, Aschkenazi S, Munoz A \& Mor G 2000 Absence of estrogen receptor-beta expression in metastatic ovarian cancer. Obstetrics and Gynecology 96 417-421.

Saunders PT, Millar MR, Macpherson S, Irvine DS, Groome NP, Evans LR, Sharpe RM \& Scobie GA 2002 ERbl and the ERb2 splice variant $(\mathrm{ERbCx} / \mathrm{b} 2)$ are expressed in distinct cell populations in the adult human testis. Fournal of Clinical Endocrinology and Metabolism 87 2706-2715.

Simpson ER 1998 Genetic mutations resulting in estrogen insufficiency in the male. Molecular and Cellular Endocrinology 145 $55-59$.

Skakkebaek NE, Rajpert-De Meyts E, Jorgensen N, Carlsen E, Petersen PM, Giwercman A, Andersen AG, Jensen TK, Andersson AM \& Muller J 1998 Germ cell cancer and disorders of spermatogenesis: an environmental connection? Acta Pathologica, Microbiologica, et Immunologica Scandinavica 106 3-11.

Song RXD \& Santen RJ 2003 Apoptotic action of estrogen. Apoptosis $855-60$.

Speirs V 2002 Estrogen receptor $\beta$ in breast cancer: good, bad or still too early to tell? Fournal of Pathology 197 143-147.

Turner KJ, Macpherson S, Millar MR, McNeilly AS, Williams K, Cranfield M, Groome NP, Sharpe RM, Fraser HM \& Saunders PTK 2002 Development and validation of a new monoclonal antibody to mammalian aromatase. Journal of Endocrinology 172 21-30.

Walker BE 1989 Animal models of prenatal exposure to diethylstilboestrol. IARC Scientific Publications 96 349-364.

Weihua Z, Makela S, Andersson LC, Salmi S, Saji S, Webster JI, Jensen EV, Nilsson S, Warner M \& Gustafsson JA 2001 A role for estrogen receptor beta in the regulation of growth of the ventral prostate. Proc Natl Acad Sci 98 6330-6335.

Yang SH, Liu R, Perz EJ, Wen Y, Stevens SM, Valencia T, Brun-Zingernagel AM, Prokal L, Will Y, Dykens J et al. 2004 Mitochondrial localization of estrogen receptor $\beta$. Proc Natl Acad Sci 101 4130-4135.

Received 19 April 2005

Accepted 13 May 2005

Made available online as an Accepted Prepreint 29 June 2005 